Pattern Prediction of Crude Oil Using Regression Moderated with Markov Switching Model. pp. 149-162

\title{
PATTERN PREDICTION OF CRUDE OIL USING REGRESSION MODERATED WITH MARKOV SWITCHING MODEL
}

\author{
Ding Zhou ${ }^{1}$, Atika Qazi, ${ }^{2,3}$, Ram Gopal Raj ${ }^{2}$, Haw Ling Liew ${ }^{1}$, Celestine .O. Eledo ${ }^{2}$ \\ ${ }^{1}$ Center of Advanced Manufacturing and Materials Processing, Department of Mechanical Engineering, Faculty of \\ Engineering, University of Malaya, Kuala Lumpur 50603, Malaysia \\ ${ }^{2}$ Faculty of Computer Science and Information Technology, University of Malaya, Lembah Pantai, 50603 Kuala \\ Lumpur, Malaysia and \\ ${ }^{3}$ Faculty of Computer Science and Information Technology, COMSATS Institute of Information Technology, \\ Islamabad, Pakistan
}

Email: atikaqazium@gmail.com² (corresponding author); zhouding@siswa.um.edu.my ${ }^{1}$ (corresponding author)

DOI: https://doi.org/10.22452/mjcs.vol32no2.5

\begin{abstract}
Scarcity of refined products for long time does contribute to economic backwardness and de-industrialization of most sub-Saharan African and the Organization of Petroleum Exporting Countries (OPEC). Institutional quality and managerial transparency absence impacted the downstream sub-sector negatively and induces Nigeria to import $80 \%$ refined products despite its huge crude oil exports. We have used Markov-switching models, a stochastic technique capable of capturing statistical knowledge to moderate Newton Series Polynomial generated on a best linear slope equation. And postulate that with less than $70 \%$ annual refinery utilization and undemocratic institutional performance, the Nigerian state will continue to experience resource curse syndrome. Continuation of Nigeria's mono-product economic structure having demonstrated a dismal performance to the economy may curse doom for the nation if it ignores calls for more domestically refined products. This paper offers an oil utilization directional guide to economic development in oil rich nations as against historical illustration of resources rich nations' failure to develop fast. However, if Nigeria chooses to maintain its current crude oil exports status industrialization is foregone.

JEL classification: $\mathrm{O11}, \mathrm{O} 2, \mathrm{O}, \mathrm{O} 2 \mathrm{2}, \mathrm{O} 38, \mathrm{O} 43$
\end{abstract}

Keywords: Downstream sub-sector, Oil utilization, Industrialization, Institutions, Markov-switching regimes

\subsection{INTRODUCTION}

Close to three decades, scarcity and inconsistent supply of refined petroleum products in resource-rich Nigeria with an average crude oil export 2001 to 2010 at $94.4 \%$ have crippled the developmental space of the nation. This has weakened the industrialization process within the country and leads to sterile economic activities in the downstream sub-sector. Furthermore, it has stalled sustainable economic development for decades and show constraint on national budget. Thus because of the continual dismal performance of the refineries functioning below $30 \%$ installation capacity over the years (see Table 1), importation of refined products to meet domestic demand become a necessity. For instance, Warri Refinery and Petrochemical Company (WRPC), and Kaduna Refinery and Petrochemical Company (KRPC) in 2007 were grounded without producing a single refined product leading to a fall in annual capacity utilization in 2007 to $8.29 \%$ only (see Table 1). Hence, the high cost of imported refined products has created a negative effect on the domestic economy due to the fuel subsidy incurred by the federal government for the expense of infra structural development throughout the country. The inconsistent supply of refined products is not peculiar to Nigeria alone, but cuts across the most sub-Saharan African (SSA) nations and some Latin American countries such as Ecuador and Venezuela members of the Organization of Petroleum Exporting Countries (OPEC). Other factors responsible for slow economic development are weak and corrupt institutions that have empowered unproductive activities, managerial opacity, resource curse, and the Dutch disease. Countries with credible institutions are free from this dilemma as the private enterprises are proactive in generating wealth for higher economic development. Whereas in weak institutions, rent seeking strives in encouraging political rent appropriation, expropriation, and crime. The stylized fact in the literature is quality institutions in resources states 
tend to grow quicker as they tend to trade more[1]. Most SSA countries and its Latin American oil producing counterparts lack quality institutional features to grow quicker.

We, therefore, focus on Nigeria downstream sub-sector and examine whether the high percentage rate of crude oil exports that leaves behind insignificant quantity for domestic refining is responsible for the economic downturn. The reference [2] describes poor institutional quality as having contributed to lower long-run Gross Domestic Product (GDP) growth of Nigeria to $0.5 \%$ annually based in 1965 and 2000 per-capita GDP figure of US\$245 that remained the same after 35 years of oil exploitation in Nigeria.

In support of the aforementioned statement, [3] claim transparent deficiency was the hallmark in the oil and gas industry, especially during the previous military regimes in Nigeria, thus posing as a challenge for economic governance. Holding to the aforementioned statements, studies by[4], [5], [6],[7], [8, 9], and [10] conclude that resource-rich countries suffer the resource curse because they are dominated by institutions that have failed to promote accountability, transparency and state competence thereby unable to improve the perverse political incentives.

Table 1: Domestic Refining Average Capacity Utilization (2001 - 2010)

\begin{tabular}{|l|l|l|l|l|l|l|l|l|l|l|}
\hline Years & $\mathbf{2 0 0 1}$ & $\mathbf{2 0 0 2}$ & $\mathbf{2 0 0 3}$ & $\mathbf{2 0 0 4}$ & $\mathbf{2 0 0 5}$ & $\mathbf{2 0 0 6}$ & $\mathbf{2 0 0 7}$ & $\mathbf{2 0 0 8}$ & $\mathbf{2 0 0 9}$ & $\mathbf{2 0 1 0}$ \\
\hline KRPC $^{1}$ & 31.39 & 34.95 & 15.96 & 26.00 & 33.08 & 8.34 & 0.00 & 19.56 & 20.02 & 20.46 \\
\hline PHRC $^{2}$ & 60.73 & 52.17 & 41.88 & 31.04 & 42.18 & 50.26 & 24.87 & 17.84 & 9.08 & 9.17 \\
\hline WRPC $^{3}$ & 48.29 & 55.53 & 14.27 & 9.10 & 54.85 & 3.85 & 0.00 & 38.52 & 43.01 & 43.36 \\
\hline $\begin{array}{l}\text { Annual } \\
\text { Capacity } \\
\text { Utilization }\end{array}$ & 46.80 & 47.55 & 24.04 & 22.05 & 43.37 & 28.82 & 8.29 & 25.31 & 24.04 & 24.33 \\
\hline
\end{tabular}

Source: "Nigerian National Petroleum Company (NNPC) Annual Statistical Bulletin 2010- 1st Edition”

Moreover, government reforms in 2003 that deregulated the downstream sub-sector due to constant short supply of refined products that has persisted since early 1970's failed because the sterile activity in the downstream sub-sector was not conducive for productive entrepreneurs. Nonetheless, the refineries' poor performance continued unabated, and recently, government intention to withdraw the fuel subsidy due to huge expenses incurred was strongly resisted by the trade unions. This prompted the federal government of Nigeria to set up a parliamentary probe on fuel subsidy. The fuel subsidy scam is out of the scope of this paper.

The Nigerian refineries no doubt has impacted negatively on the growth and development throughout the economy in many ways. The inconsistent supply of refined products has undermined an industrialization process throughout the country, leading to industrial workers' retrenchment and increase unemployment figures. Furthermore, fuel subsidies by government also encouraged fuel smuggling across border and thus increase fuel scarcity level the more. Others are increased of rent seeking activity and corruption prevalence in the downstream sub-sector of the oil industry aid to destroy the production sector.

Predictions to examine whether the Nigerian state can surmount the scarcity of petroleum products to revive its ailing industrial sector; Creating jobs in harnessing growth and development and thus prompt rapid economic development based on the current data set was conducted. Moreover, the oil and gas prediction for the year, 2011 to 2019 from this study will give a directional economic development information guide. Since it seems there is no

\footnotetext{
${ }^{1}$ KRPC stand for Kaduna Refinery and Petrochemical Company

2 PHRC stand for Port-Harcourt Refinery Company (1 and 11)

3 WRPC stand for Warri Refinery and Petrochemical Company
} 
trace of any directional development prediction on the downstream sub-sector of the economy apart from historical illustration and the conventional fact of slow economic growth deduction on oil rich nations.

In this paper, we propose Markov-switching models (MS models), a machine learning model built on pattern prediction of oil and gas data set. MS is stochastic models, dynamic and competent of handling statistical knowledge and categorization and introduced into economics by [11]. The proposed model addresses the refined product's scarcity problem by proposing three regimes of MS models. The first regime represents the current situation of less than 30\% refinery capacity and feeble institutions. The second regime considers more than $30 \%$ and less than $70 \%$ refinery capacity and feeble institutions, and the third regime considers $70 \%$ and above refinery capacity and quality institutions. We, therefore, determine which of the three regimes is most viable to the Nigerian economy while measuring the output of the regimes respectively.

We find that the current crude oil "high" exports persistence level is not favorable to the Nigerian economy just as the first regime of less than $30 \%$ refinery capacity and weak institution illustrates. If no significant change is implemented in reducing the quantity of crude oil exports, definitely no significant per cent of its oil will be available for refining from 2015 onward. This unfortunately signals the country non-readiness for industrialization but chose to remain at the negative growth level for many years. As for the second regime, if oil exports policy favors significant domestic refining, performance fluctuates between moderate growth and rapid growth regimes as it lacks quality institutions to stabilize the economy. Also, if oil exports policy favors significant domestic refining in the third regime, its operation will be at the optimal point of rapid growth and development with $70 \%$ and above the refinery capacity builds on quality institution. This illustrates that our proposed model can explain the regimes features over the years ahead.

The rest of this paper is organized as follows: Section 2 reviews the related literature; section 3 discusses the methodology; section 4 is on extrapolation of oil production and exports figure. Section 5 presents the results and discussions; while the last section 6 concludes the study.

\subsection{RELATED LITERATURE}

\subsection{Theoretical Consideration}

Quite a reasonable number of literature has sought to proffer reasons of retardation in economic growth and development of rich resource nations. The literature recognized the effects and importance of institutions in economies. In view of this, [12] [13], and [14] describe natural resource abundance as being a blessing or a curse for economic development in rich resource countries, rest on the quality of the institutions in the country. In addition, [6] investigate the effect of natural resource abundance on institutional quality, and grouped institutions into two strands, the grabber friendly and the producer friendly institutions. The grabber friendly institution is prevalent when development and handling of the economic situation increase unproductive actions as economic activities compete instead of complementing each other. This is ascribable to weak rule of law, and weak and corrupt institutions. The present of a weak institution empowers the government to treat public workers shabbily. This gives an insight into, [15], and [16] reason that rent seeking necessitates government to hold salaries low, aware of the unproductiveness of the state. Further, the friendly productive institutions are preferable to economic operations where there is a free enterprise that generates wealth. In fact, quality institutions are complementary when the productive actions and rents create wealth via private enterprises. In [17] it report that growth spell limited period of time in sub-Saharan African and Latin American countries is due to the degree of democratic institutions as compared to industrialized countries.

In [12] and [18] suggest that grabber friendly institutions push aggregate income down by turning entrepreneurs away from production and into infertile rent appropriation, while primary resources in producer friendly institutions increase income by attracting entrepreneurs. They emphasized that in a weak institution rent, seeking strives in encouraging political rent appropriation, expropriation, crime and warlords. These actions we acknowledge as facts advancing economic slump. In [19], [20] investigate reasons that prolong the continuity of weak institutions in the polity in spite of the negative effect generated. They hinge upon the result of their findings on the perseverance of de jure and de facto political authority in all political settings. Hence, they found that the opposing institution's 
existence is owed to their sources and use of political power, even when there is a change of governance. These findings support the trend that despite losing patronage politically, the elites still increase their lobbying, rent seeking and inducement to exert disproportionate influence in politics. Unfortunately, an incompetent bureaucratic establishment is gateways that foster rents; destroy productivity and retard economic growth. Though [12], and [19] examine grabber friendly institutions and persistence of de jure and de facto in the political setting, their results on rent's effects in the economy converge.

On the theory of rent seeking and a case study on the timber boom in Southeast Asia, [9] presents a situation of how the sudden resource's booms of timber in the international markets can injure developing nation's institutions. A turnaround situation of resource booms in timber exports sadly led to the decay and breakdown of once acclaimed strong forestry institutions in Southeast Asia that was induced by government policies. Unfortunately, most developing countries dependent on natural resources, agricultural products, and points resources suffer the same feat. In [9] claims that scholars hold different perspective's opinion if the resource boom is indeed a curse or a blessing. According to Ross, classical theories of economic development postulate rich resource states that experience commodity booms will grow quicker. But other schools of taught hold that the resource booms will turn resource-rich nations into violent commotion as a result of the sharp increase of primary product. This proposition is well described and quite prevalent in SSA nations. This is why the negligible number of states was unable to administer resources booms but instead get ruined by its natural endowment.

The stylized fact in the literature is that quality institutions in resource states tend to grow faster as they tend to trade more, according to [1]. Using a large cross-section of countries, they found quality institutions; trade intensity and speedy growth in the long run forge together for economic growth. Though 21] differ from [1] with the inclusion of trade volatility and over-valuation of exchange rate in their proposal as reasons for slow growth of rich resource nations, both agree with the importance of quality institutions in economic growth. They found weak institutions in rich resource countries negatively impact growth while quality institutions impact growth positively, and support the findings of [14], [22], [6]. In addition, [17] report that growth spell limited period of time in sub-Saharan African and Latin American countries is due to the degree of democratic institutions as compared with industrialized countries. Drawing illustrations on Nigeria, Sala-i-Martin in [21] describe the meager run of economic growth encountered as not related to "Resource Curse" per-se but rather due to corruption and wasteful of resource income. Surprisingly, this has been a contributory factor of most SSA nations because they were unsuccessful to manage for institutional quality. To this, [23] considers corruption as enriching private life from government coffers to the neglect of the need as a nation. When allocations meant for public goods are misplaced and diverted into private purposes the masses suffer. However, [24] refers to corruption as misappropriation of funds, perversion of public authority and favoritism. This definition of corruption is broader than [23]. Furthermore, [25] argues that corruption in Ghana is taken as rent seeking behavior, which diverts resources from productive means.

In [26] authors investigate the impacts that constrain economic development in Nigeria in the past four decades using co-integration and error correction framework. They found social and economic factors as a responsible constraint to economic development of the country. The social restraining component identified is corruption, rents, and the economic factors comprise infrastructure and human capital. These findings from a study covering forty years of Nigeria's existence portray the state of the country under the military regimes and civilian dispensation and this supports the views of [27]. In [28] author argues that corruption and rent seeking differs in nature, quality, form or degree, though, he maintains that the differences get blurred later on. Groningen Corruption Perception Index that records Botswana as Africa's best performer and Norway's richness in Europe attributing the success to quality institutions thus supports the rent hypothesis theory.

Hence, having considered institutions and rent seeking theory next is the resource curse and Dutch disease. In resource curse theory, economies with resource abundance are prone to slow economic growth in comparison to scarce resource's countries according to [29, 30], [31] high levels of oil are stable. Presented research in [29], and [31] find that nations with limited resources tend to grow faster than nations with abundant resources but less dense population. Many scholars have examined the negative relationship of natural endowment, growth and economic performance. Indeed, huge bodies of experiential work with proof seem to confirm the negative relationship between resource abundance and poor economic performance. But ordinarily, nations that accrue huge revenues ought to yield wealth in an economy, encourage economic progress and reduce poverty from natural affluence. The state of difficulty fashioned by natural endowment is not exclusive but generic as crude oil exporters endure a bunch of 
economic contraction. The study by [32] examines the association of the oil proceeds-growth non-linearity and from 1965-2005 appraised the gateway of 13 oil-exporting countries' oil revenue. The study observes a positive correlation between development and oil returns on the merit of spline technique applied. The positive relation existing below the $18 \%$ threshold is further supported by the structural break but any returns above the threshold turned to a negative relation. This latter finding supports the trend of findings on a resource curse while in the former, if the oil revenue is modest and below the expected threshold, it's a blessing. This paper differs as it tends to limit oil-exporting countries to $18 \%$ threshold level, which is relatively low and unacceptable to most SSA nations. The study [33] suggests the Dutch disease booms impact development negatively as the relative size of the secondary sectors suffers due to neglect, and more workforces lose jobs because of low productivity. Hence, the oil boom afflicted the Nigerian economy and with it came the 'Dutch disease", the existence of vast natural resource of wealth and poverty in developing economies like Nigeria. Also, [29] justify the frustration of economic growth evident in 11 Latin American economies due probably to Dutch disease from 1960 to 1994. The Dutch disease phenomenon used to analyze the effects of commodity booms are traditionally evaluated in terms of cost and resource movement effects [34]. Though the results in SSA oil exporters tend to suggest the presence of a resource curse, but the curse lies with leadership attributes made manifest in ruling and misappropriation of resources [35]. Duruigbo in [35] insists the leadership failed to put in justified management structures that are beneficial for the masses and that significant adjustment certainly will experience central changes, thus deviating from the standard definition of Dutch disease.

Ogunleye in [36] examines the impact on Nigeria's economic growth, and development bases on its rich-oil wealth and per-capita GDP economic indicators modeled with vector error-correction model. He established the negative effect on per-capita household consumption, manufacturing and agriculture resulting from an increase in per-capita oil revenue. The presence of a damaging connection between oil and gas sector, and the non-oil sector is well described (see Ogunleye, op.cit). Also, the comment offers considerable insight to the damaging increment effects of the resource curse. In [28] alleges resource curse engenders poverty, worsen income inequality and in addition rich resources economies have a poor record in poverty reduction apart from a negative growth effect upon economic development. From the above discussion, it is clear that the SSA poverty rate and income inequality are unabated.

In all, there is evidence of growth winners and losers despite the claim of negative relationship between natural resource abundance and growth. Botswana rich in diamond is a winner having the highest growth rate for five decades. The presence of quality institutions contributed immensely to oil exploration and economic development in Norway. Undoubtedly, the society loses consistently from weak institution, resource curse, Dutch disease and corruption. Weak institution allows incompetent entrepreneurs in industry, empowers fraudulent administrators and awful economic strategy by the management. Natural endowment ceases to impact economic development negatively when quality institution is in place.

\subsection{METHODOLOGY}

The Hidden Markov Models (HMMs) have earned its popularity in non-economics and economics domain largely from successful applications to speech recognition [37, 38], and in computer vision [39]. The HMMs also have been applied in handwriting recognition, gene sequencing, and gesture recognition and broadly used in psychology of learning. In economics, the HMMs is used to examine the US business cycle [40], stock market volatility [11], and foreign exchange rates [41].

An econometric theory of predicting statistical time series using Markov switching vector auto regressive model (MS-VAR) was proposed by [42]. It addresses the baffling problems linked to the forecasting performance of nonlinear time series models and regimes switching models. The model is chosen due to its flexibility of creating suitable models for prediction and the demonstration that during recessions, models built on three regimes forecast better. MS-VAR models are characterized with an effortless means of forecasting as long as the auto regressive parameters are regime invariant.

The multi-regime Markov-switching Vector Autoregressive model (multi-regime MS-VAR) [43] examines the stochastic regime shifts of US, Japan and some Southern European economic growth. It is an extension of [40] analysis of the US business cycles for the statistical measurement of macroeconomic variations. Due to the structural change's evidence in the economies of these nations that have manifested in the long run mean growth rate and in the volatility of growth, the regimes are therefore extended to three regimes from the initial two "conventional" 
regimes to accommodate the observed development processes. The multi-regime MS-VAR models, therefore, assist to establish the presence of nonlinear commercial cycles, organizational changes noticeable in structural breaks, and the instability observed during the growth process. Analyzing the three regimes macroeconomic fluctuations statistically gets simplified. It is employed to scrutinize regime shifts in the random process of economic progress four decades ago in the United States, Japan and Europe. The regimes analyzed the rapid growth regime that reveals structural change and prevails over the other two regimes. While the recession and normal expansion regimes fluctuate between phases within the growth cycle.

Growth determinants vary from country to country and accounts for reasons of variation in economic development among nations. Equally, characteristics that affect the average expansion differ from one industry to another industry. In estimating growth of refined products in Nigeria, the under-mentioned factors are considered as the form

$$
\hat{y} t i=\alpha+\beta y t i+y z i+\varepsilon i
$$

Where $y t i$ is the output of refine products over time t, $\alpha$ is a constant, $y t i$ is oil available for refinement after exports intended to get the convergence effect, ${ }^{y z i}$ is measuring refinery capacity and institutional quality that affect the level of output, and $\varepsilon i$ the weighting of the parameter of the model. The capacity utilization of the refinery and the institutions determine to a great extent the quantity of refined products produced.

The $\mathrm{z}$ variables above and its measures determine the level to which it impacts average expansion. Though, some scholars see quality institutions as a sluggish variable but do acknowledge it robustness [44]. But Acemoglu and Robinson [5, 45, 46], Ross [8, 9], Acemoglu et al. [20], Sala-i-Martin and Subramanian [21], Isham et al.[13], and Mehlum et al. in [6] describe institutions as the pivot of any developmental progress in a nation. Once it is controlled, the economy will experience stable growth. We follow the three regimes switching model of Kroliz [42] and classified the current patterns as recession, moderate growth, and rapid growth.

In order to determine the best linear slope for the oil production and oil export data, we used the following formula:

Average slope of the graph

$\begin{array}{rl}\mathrm{j}=1 & \mathrm{i}=0 \\ \mathrm{MAVG}=\{\Sigma \quad \mathrm{j}=\mathrm{n} \quad[\Sigma & \mathrm{i}=\mathrm{n} \quad(\mathrm{yi}+\mathrm{j}-\mathrm{yi}) /(\mathrm{xi}+\mathrm{j}-\mathrm{xi})]\} /\{\mathrm{n} .[((\mathrm{n}+1) / 2)-1]\}\end{array}$

This equation takes into account all the data points for each year in relation to every other, thus producing a clearer representation of the trend of a set of data. Once the average slope is found, we created a Newton Series of the Data and extrapolated the future data points to an average of the Newton Series data points and the data points generated using MAVG. The Newton Series Polynomial is given by:

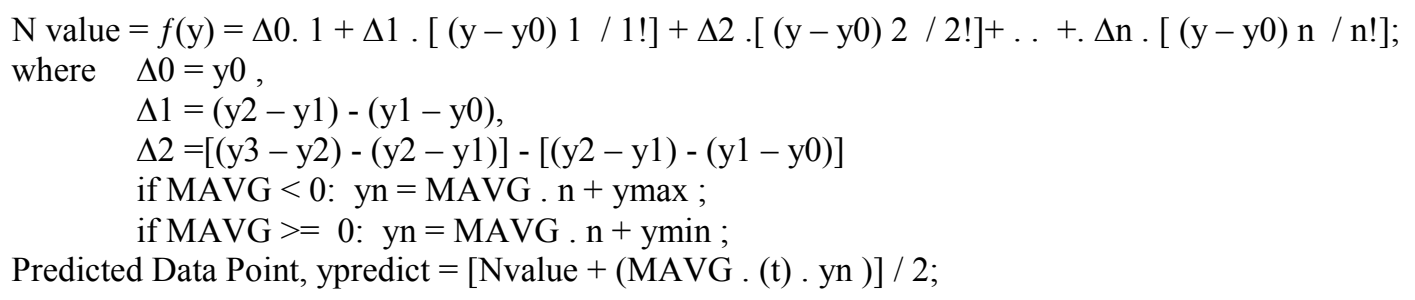

Where $\mathrm{t}=$ Number of Years after $\mathrm{n}$ the prediction is being made. 
We combine and refine the polynomial using a Markov Switching Model as follows:

We do not directly observe the latent state vector Mt. Based on the existing oil data, we define the conditional probabilities:

$$
\begin{aligned}
& \mathrm{j}=1 \\
& \Pi \quad \mathrm{j}=\mathrm{n} \quad=\mathrm{P}(\mathrm{Mt}=\mathrm{mj} \mid \mathrm{r} 1, \ldots, \mathrm{rt})
\end{aligned}
$$

$1 \quad d$

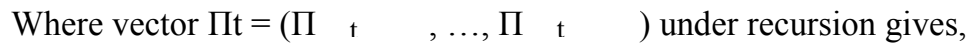
$\Pi \mathrm{t}=[\omega(\mathrm{rt}) .(\Pi \mathrm{t}-1 . \mathrm{A})] /\left\{[\omega(\mathrm{rt})\right.$. (Пt-1 . A) $\left.] 1^{\prime}\right\}$

Where $1=(1, \ldots, 1) \in \operatorname{Rd}, \mathrm{x} \cdot \mathrm{y}=(\mathrm{x} 1 . \mathrm{y} 1, \ldots, \mathrm{xd} \cdot \mathrm{yd})$ for all $\mathrm{x}, \mathrm{y} \in \mathrm{Rd}$, and

$\omega(\mathrm{rt})=[f(\mathrm{rt} \mid \mathrm{Mt}=\mathrm{m} 1) ; \ldots ; f(\mathrm{rt} \mid \mathrm{Mt}=\mathrm{md})]$ and

Initial Vector, $\Pi 0=1 / \mathrm{d}=2-\breve{\mathrm{k}}$ for all $\mathrm{j}$;

On the other hand, the following secondary database on Nigeria's crude oil was sourced early this year 2012 for use in this paper. The crude oil production (Table 2) depicts the comprehensive data on crude oil mined from 2001-2010 on the monthly basis. The crude oil exports (Table 3) accounts for Nigeria total exports revealing the percentage of crude oil exported. The domestic refinery capacity utilization per cent (Table 1), and (Table 4) petroleum products imports [1] record each monthly refinery performance and Nigeria level of imported refined products and its components respectively. For each of the data collated, it covers 10 year duration from 2001 to 2010 . These data are collected from Nigerian National Petroleum Corporation (NNPC) annual statistical bulletin 2010 1st edition. NNPC is an official corporation established in 1977 to oversee the on-shore and off-shore oil and gas exploitation in Nigeria. This study covers the sample period from 2001 to 2010.

Table 2: Crude Oil Production 2001 - 2010 (barrels)

\begin{tabular}{|l|l|l|l|l|l|l|l|l|l|l|}
\hline Year/Month & 2001 & 2002 & 2003 & 2004 & 2005 & 2006 & 2007 & 2008 & 2009 & 2010 \\
\hline Jan. & $75,357,274$ & $67,478,748$ & $73,55,292$ & $77,878,402$ & $75,540,957$ & $80,142,250$ & $71,906,265$ & $67,122,292$ & $63,052,811$ & $72,293,218$ \\
\hline Feb. & $68,894,274$ & $55,214,025$ & $67,360,682$ & $72,932,473$ & $68,673,52$ & $69,066,704$ & $64,750,156$ & $60,380,977$ & $57,525,048$ & $66,783,558$ \\
\hline Mar. & $74.752,675$ & $60,778,550$ & $68,911,052$ & $79,004,685$ & $77,139,546$ & $69,633,805$ & $66,216,317$ & $64,003,319$ & $63,607,293$ & $75,565,354$ \\
\hline Apr. & $72,934,730$ & $58,888,031$ & $65,537,307$ & $75,047,933$ & $73,936,531$ & $69,553,636$ & $64,669,404$ & $58,904,988$ & $55,810,242$ & $72,418,124$ \\
\hline May & $72,297,504$ & $59,362,697$ & $69,176,036$ & $76,010,305$ & $77,878,044$ & $70,816,217$ & $60,649,421$ & $63,566,972$ & $66,789,298$ & $70,145,455$ \\
\hline June & $68,333,658$ & $57,085,986$ & 66245,835 & $74,851,145$ & $75,423,440$ & $72,255,218$ & $62,433,727$ & $60,542,721$ & $64,656,068$ & $71,923,986$ \\
\hline July & $70,468,689$ & $56,085,986$ & $69,119,539$ & $77,678,945$ & $77,794 ., 986$ & $74,144,673$ & $67,338,234$ & $66,088,254$ & $61,803,445$ & $77,702,274$ \\
\hline Aug. & $73,750,870$ & $65,315,227$ & $71,513,748$ & $78,246,683$ & $77,691,546$ & $74,469,345$ & $67,125,776$ & $65,255,620$ & $67,236,056$ & $77,702,274$ \\
\hline Sept. & $72,329,172$ & $64,839,433$ & $68,722,694$ & $74,809,921$ & $77,510,783$ & $71,998,966$ & $69,216,517$ & $65,157,891$ & $66,204,265$ & $77,80,777$ \\
\hline Oct. & $73,995,816$ & $62,582,417$ & $74,63,318$ & $76,276,646$ & $79,088,685$ & $73,822,688$ & $71,990,272$ & $70,207,660$ & $70,635,425$ & $81,196,554$ \\
\hline Nov. & $70,779,990$ & $65,576,846$ & $73,344,267$ & $74,028,879$ & $77,141,915$ & $70,132,586$ & $67,369,351$ & $64,197,050$ & $73,122,964$ & $73,000,691$ \\
\hline Dec. & $71,278,931$ & $67,480,783$ & $76,075,159$ & $73,390,469$ & $80,840,614$ & $73,160,418$ & $68,335,351$ & $63,321,188$ & $73,122,964$ & $80,133,737$ \\
\hline Total & $65,173,583$ & $740,687,180$ & $844,150,929$ & $910,156,486$ & $918,660,619$ & $869,196,506$ & $803,000,708$ & $768,745,932$ & $780,347,940$ & $896,043,406$ \\
\hline
\end{tabular}

Source: "NNPC Annual Statistical Bulletin 2010- $1{ }^{\text {st }}$ Edition" 
Table 3: Crude oil export 2001-2010 (barrels)

\begin{tabular}{|c|c|c|c|c|c|c|c|c|c|c|}
\hline Year/Month & 2001 & 2002 & 2003 & 2004 & 2005 & 2006 & 2007 & 2008 & 2009 & 2010 \\
\hline January & $72,723,164$ & $57,284,626$ & $63,927,693$ & $75,326,188$ & $67,456,297$ & $71,062,565$ & $70,552,458$ & $56,793,954$ & $57,920,658$ & $67,145,981$ \\
\hline February & $58,619,463$ & $51,015,787$ & $64,213,985$ & $73,082,052$ & $62,778,435$ & $66,829,351$, & $58,955,150$ & $63,301,288$ & $57,280,104$ & $67,468,691$ \\
\hline March & $69,702,192$ & $53,833,912$ & $62,890,237$ & $75,697,415$ & $70,156,144$ & $66,289,600$ & $63,803,365$, & $59,582,300$ & $63,302,134$ & $70,768,401$ \\
\hline April & $63,839,139$ & $50,552,697$ & $62,068,333$ & $72,073,593$ & $63,695,905$ & $63,576,833$ & $63,456,666$ & $54,376,043$ & $53,621,759$ & $67,260,046$ \\
\hline May & $65,871,650$ & $52,706,783$ & $67,533,578$ & $73,105,924$ & $75,223,196$ & $65,258,457$ & $63,129,755$ & $62,968,369$ & $68,367,535$ & $67,550,277$ \\
\hline June & $64,153,812$ & $52,177,133$ & $63,036,788$ & $72,205,187$ & $67,719,039$ & $68,187,970$ & $61,246,627$ & $54,265,316$ & $62,116,894$ & $74,591,290$ \\
\hline July & $62,581,831$ & $53,453,914$ & $64,221,785$ & $75,792,843$ & $75,770,411$ & $72,460,015$ & $70,740,161$ & $57,417,639$ & $61,994,406$ & $75,843,753$ \\
\hline August & $66,896,170$ & $56,530,296$ & $70,581,872$ & $76,725,509$ & $70,382,521$ & $67,340,856$ & $63,249,478$ & $60,596,105$ & $66,450,920$ & $69,009,003$ \\
\hline Sept. & $64,658,699$ & $57,308,222$ & $67,776,052$ & $74,100,218$ & $69,157,525$ & $64,917,141$ & $70,353,429$ & $64,361,582$ & $63,242,730$ & $77,962,880$ \\
\hline Oct. & $66,537,511$ & $58,414,515$ & $68,273,106$ & $71,407,315$ & $68,979,056$ & $70,966,162$ & $68,214,009$ & $68,072,988$ & $71,442,502$ & $76,732,148$ \\
\hline Nov. & $61,734,194$ & $57,415,035$ & $68,883,971$ & $68,135,235$ & $74,118,223$ & $70,727,123$ & $65,930,520$ & $61,136,734$ & $64,972,801$ & $71,161,171$ \\
\hline Dec. & $57,858,003$ & $62,700,455$ & $72,577,078$ & $70,425,870$ & $78,714,746$ & $70,379,949$ & $72,194,901$ & $61,607,478$ & $78,482,761$ & $79,208,460$ \\
\hline
\end{tabular}

Source: "NNPC Annual Statistical Bulletin 2010- ${ }^{\text {st }}$ Edition"

Table 4: Petroleum products imports (2001-2010)

\begin{tabular}{|l|c|c|c|c|c|c|c|c|c|c|}
\hline $\begin{array}{l}\text { Year/ } \\
\text { Products }\end{array}$ & 2001 & 2002 & 2003 & 2004 & 2005 & 2006 & 2007 & 2008 & 2009 & 2010 \\
\hline PMS. & $3,857,093$ & $4,036,484$ & $5,404,163$ & $5,696,399$ & $5,482,81 \beta$ & $5,407,634$ & $5,792,449$ & $4,596,145$ & $5,988,567$ & $5,031,288$ \\
\hline HHK & 433,295 & N/A & 637,621 & 418,245 & 671,939 & $1,081,503$ & $1,335,022$ & 909,542 & $1,170,993$ & $1,608,464$ \\
\hline AGO & 117,156 & 404,897 & $1,146,685$ & 211,471 & N/A & N/A & N/A & N/A & N/A & N/A \\
\hline LPG & N/A & 94,351 & N/A & 170,279 & N/A & N/A & N/A & N/A & N/A & N/A \\
\hline TOTAL & $4,407,544$ & $4,535,732$ & $7,188,469$ & $6,496,394$ & $6,154,752$ & $6.489,137$ & $7,127,471$ & $5,505,687$ & $7,159,560$ & $6,639,752$ \\
\hline
\end{tabular}

Source: "NNPC Annual Statistical Bulletin 2010- 1st $^{\text {st }}$ Edition"

PMS: Premium motor spirit

HHK: House Hold kerosene

AGO: Automotive gas oil and

LPG: Liquefied petroleum gas 
Based on the extrapolation of the data, we obtain the following figures.

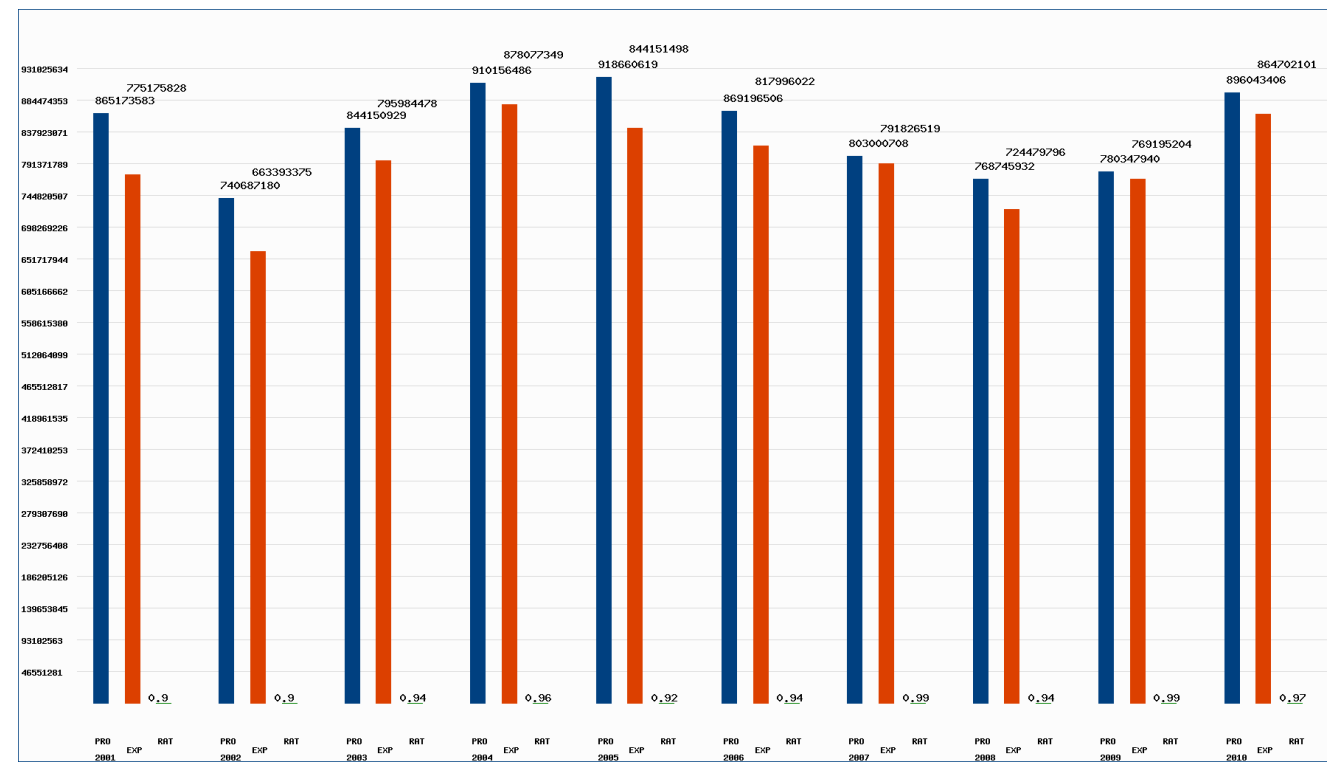

Fig. 1: Oil Production (Pro, blue) and Export (EXP, red) and Production to Export Ratio (RAT, green) Estimates from 2001 to 2010

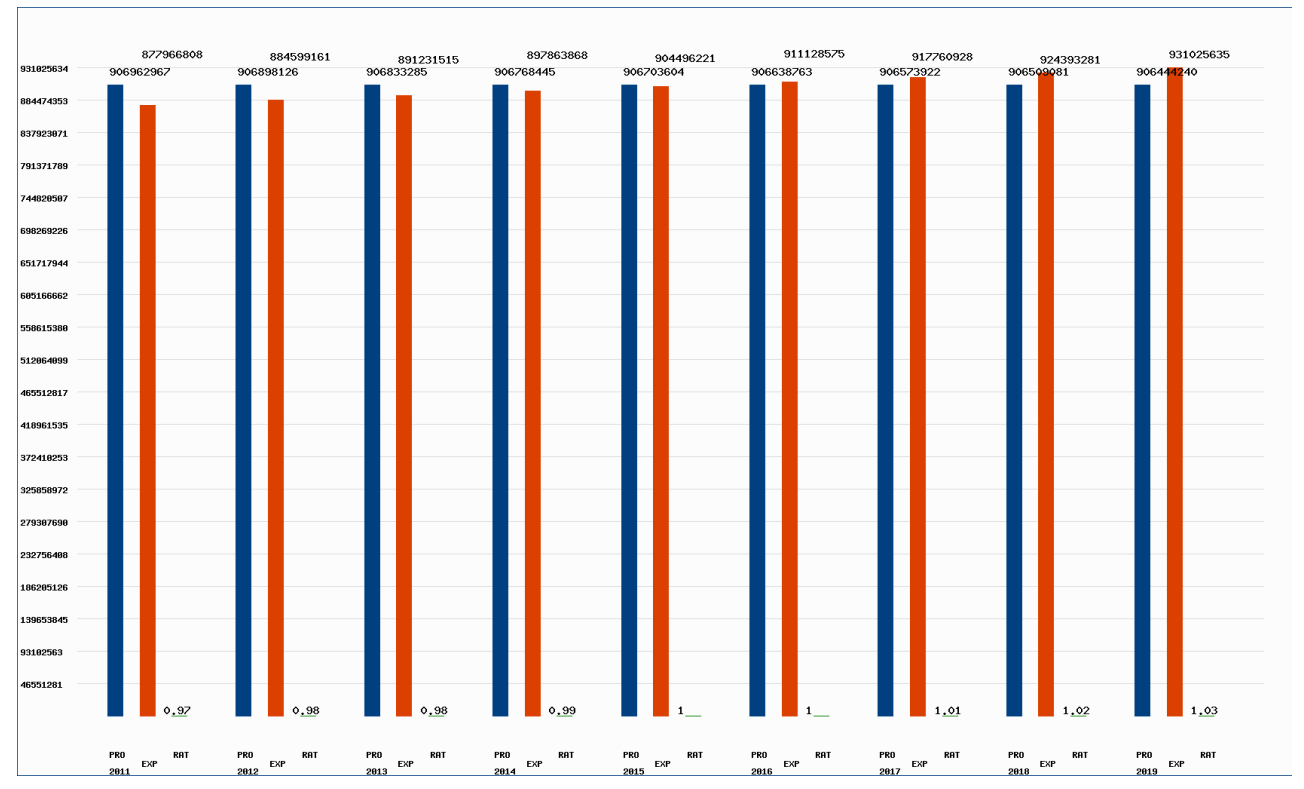

Fig. 2: Oil Production (Pro, blue) and Export (EXP, red) and Production to Export Ratio (RAT, green) Estimates from 2011 to 2019 


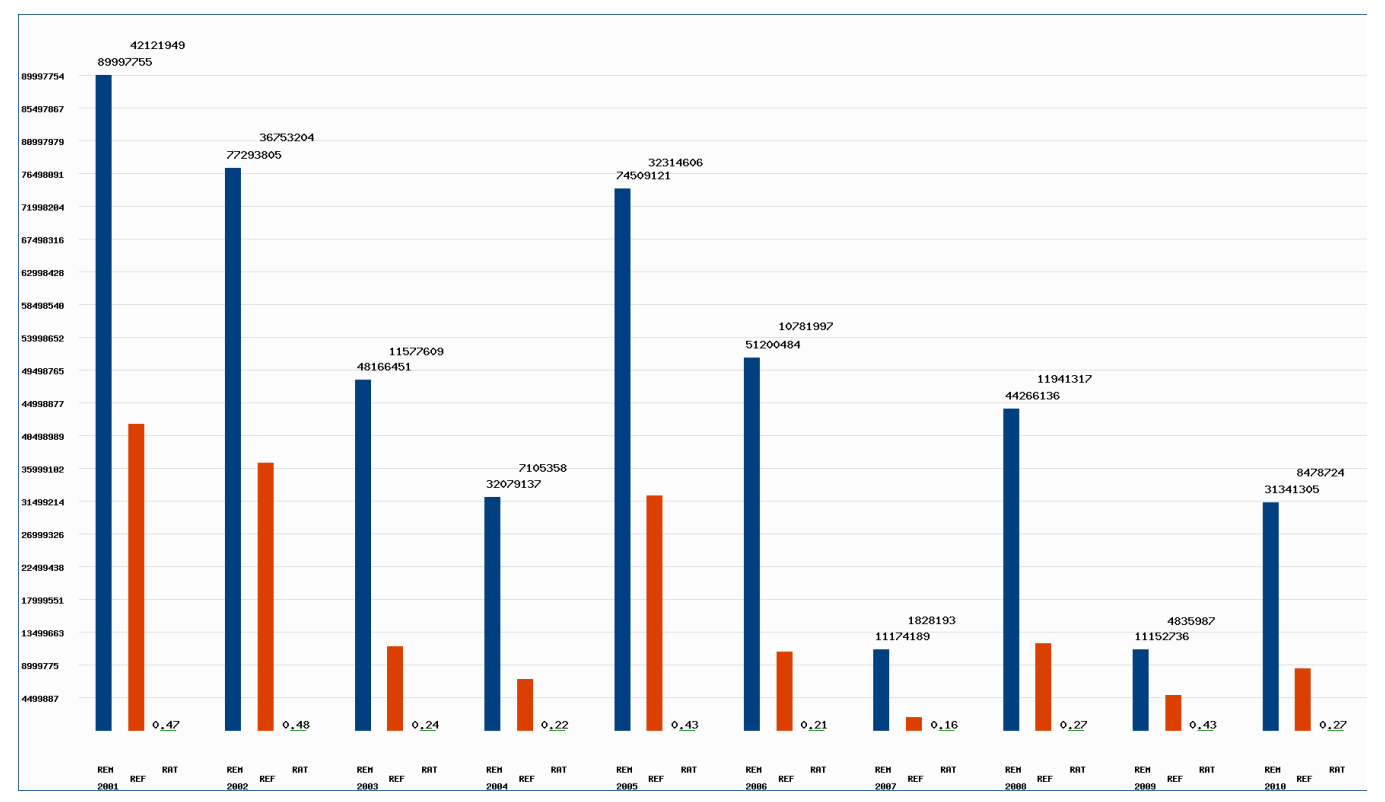

Fig.3: Oil Available for Refinement after export (REM, blue) and Refined Oil Estimates Based on available refinery capacities (REF, red) and Remainder to Refined Ratio (RAT, green) Estimates from 2001 to 2010

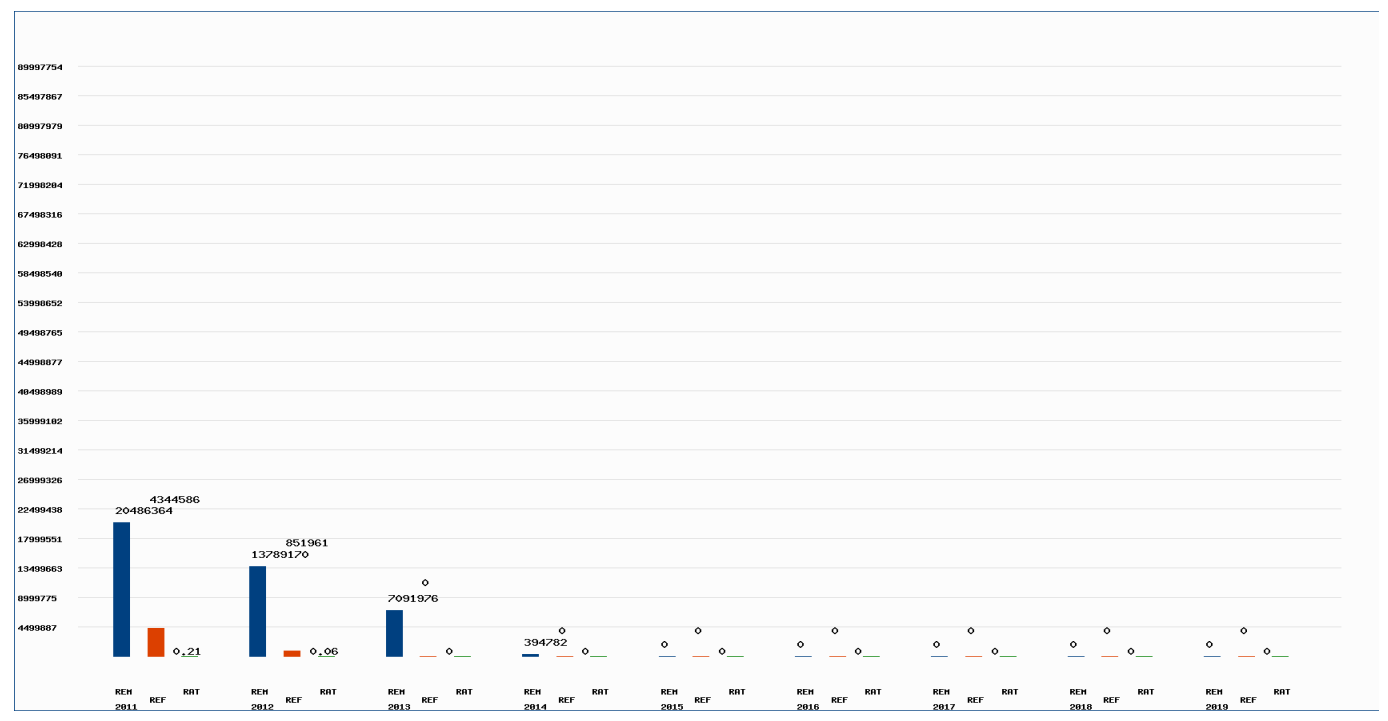

Fig.4: Oil Available for Refinement after export (REM, blue) and Refined Oil Estimates Based on available refinery capacities (REF, red) and Remainder to Refined Ratio (RAT, green) Estimates from 2011 to 2019

\subsection{RESULTS AND DISCUSSIONS}

The results of the extrapolation of oil production and exports as shown in section 5 definitely account for slow economic growth as noted in the literature. Figure 1 is the translation of (Tables 2 and 3) into a clear view of oil and gas production and export's situation in Nigeria from the year 2001 to 2010. The oil production and exports estimates of 2011-2019 (Figure 2) paints a gloomy future for the economy industrially, as its oil exports' clock close to 100 per cent in 2015. The country oil and gas exports will be 98, 98, and 99 per cent in 2012, 2013, and 2014 respectively before heating 100 per cent in 2015 . The oil estimates are disturbing and indicate that in 2015 Nigeria might be exporting virtually all its oil production with less than 2 million barrels for refining purposes if it keeps to the current trend of its crude oil exports tradition that has been on for the past decade. The estimates in (Figure 3) 
show a gradual slope down to the right representing a reduction of the crude oil remainder for use domestically and for refining after close to $90 \%$ of total oil production has been exported in 2001. Moreover, similar sloppy condition is noticeable in domestic refined production respectively. The quantity refined to keep decreasing from year 2001 to 2004 before experiencing a sharp rise in 2005 due to increase in the annual capacity utilization to $43.37 \%$ in 2005 from $22.05 \%$ in 2004 . Consequently, cruel oil reminder in 2005 had a $100 \%$ increase from year 2004 estimate because of an improve performance of the refinery in 2005 (see Figure 3). But ever since 2006 refined product's estimate has seriously been on the downward trend establishing facts that the refineries are grossly underutilized.

The results depicted in (Figure 4), oil available for refining and refined oil estimate are quite alarming as the estimates from 2011 to 2019 indicate. As the available oil for refinement purposes decreased drastically due to 100 per cent oil exports marks, same trends are observable on quantity of refined products produced. For instance, only 0.2 percent and 0.06 percent are refining in 2011 and 2012 respectively. But in 2013, out of the meager 7 million barrels estimated to be available for refining, zero per cent refined products is expected. Similar distressing trend of zero per cent refined products will continue in 2014 through 2019. The gradual petroleum products import increase observable since 2001 is still on-going. With situation as bad as this, can the nation be industrialized.

Our results support previous findings on rich resource's countries inability to grow as fast as scarce resource's nations Sachs and Warner (1997 and 2001), Auty (2001), Basedau and Lacher (2006). Also, Jesuleye et al. (2007) draw the energy policy implications on Nigeria thus; if the most resourceful and advanced refinery like the PortHarcourt refinery could be inefficient, invariably the other two refineries will be and if this trend is not reversed, after that in future the refineries will be redundant. The option of imported refined products to meet domestic consumption will afterwards be harmful to economic development. These findings extend the theory of resource's curse and reveal that without a structural change in Nigeria's crude oil exports policy, the downstream sub-sector will run out of crude oil for refining purposes in due time. This will add to the retardation of its economic development processes. Our findings defined statistically the economical institutional impact over a long period of time unlike historical illustration. Our estimates show that this trend may continue without a sign of revival due to the continual low performance of the refinery.

\subsection{CONCLUSION}

The intention of this paper was to examine how the downstream sub-sector can be used as an engine of industrialization in the economy. However, unfortunately, the downstream sub-sector of the oil industry has proven unproductive and incapable of surmount the scarcity of petroleum products to revive the nation industrial sector, generate employment and create a working environment to generate wealth. For Nigeria to attain refined petroleum products sustainability and economic development its downstream sub-sector must improve beyond the present limit, and restructure crude oil exports policy to the benefit of substantial domestic refining. The Markov-switching models built on oil and gas pattern prediction because of its ability to handle statistical knowledge and categorization were used for the prediction process. Since the usage of oil and gas in the 21 st century differs completely from it uses in the 19th and 20th centuries, developing countries need to take a clue from industrialized countries, which refine close to 60 per cent of their oil production while it exports the rest. In addition, it must embrace quality institutions, as its oil sector's experience, nearby 50 years is a glaring indication of institutional failure having been unsuccessful in accomplish economic sustainability with its oil wealth. The moves if purposely driven will turn the economy around for good. The benefits of refining reasonable quantity of oil domestically most likely surpass the exportation of virtually total crude oil production, as it fosters economic development in various ways. Generating significant foreign exchange revenue from refined products apart from the reawakening of the industrial sector would be of a huge benefit in facilitating rapid economic growth and development. Therefore, failure to usher in a quality institutions in the downstream sub-sector of the oil industry, the natural endowment would continue to exhibit a sign of affecting the economic development negatively. For future work, we intend to examine core institutional reforms that will activate rapid economic development.

\section{ACKNOWLEDGEMENT}

We express our appreciation to the late Celestine .O. Eledo, whose contribution to this work was of great significance. 


\section{REFERENCES}

1. Dollar, D. and A. Kraay, InstItutIons, Trade and Growth: Paper prepared for the CarnegIe-Rochester Conference SerIes on Public PolIcy. The World Bank, 2002.

2. Artadi, E.V. and X. Sala-i-Martin, The economic tragedy of the XXth century: growth in Africa, 2003, National Bureau of Economic Research.

3. Okonjo-Iweala, N. and P. Osafo-Kwakko, Nigeria's economic reforms: Progress and challenges. 2007.

4. Robinson, J.A., R. Torvik, and T. Verdier, Political foundations of the resource curse. Journal of development Economics, 2006. 79(2): p. 447-468.

5. Acemoglu, D. and J. Robinson, The role of institutions in growth and development. 2010: World Bank Publications.

6. Mehlum, H., K. Moene, and R. Torvik, Institutions and the resource curse. The economic journal, 2006. 116(508): p. 1-20.

7. Gelb, A.H., Oil windfalls: Blessing or curse? 1988: Oxford University Press.

8. Ross, M.L., The political economy of the resource curse. World politics, 1999. 51(2): p. 297-322.

9. Ross, M.L., Timber booms and institutional breakdown in Southeast Asia. 2001: Cambridge University Press.

10. Budina, N. and S. van Wijnbergen, Managing oil revenue volatility in Nigeria: The role of fiscal policy. Africa at a turning point, 2008: p. 427-60.

11. Hamilton, J.D. and R. Susmel, Autoregressive conditional heteroskedasticity and changes in regime. Journal of econometrics, 1994. 64(1): p. 307-333.

12. Mehlum, H., K. Moene, and R. Torvik, Cursed by resources or institutions? The World Economy, 2006. 29(8): p. 1117-1131.

13. Isham, J., et al., The varieties of resource experience: natural resource export structures and the political economy of economic growth. The World Bank Economic Review, 2005. 19(2): p. 141-174.

14. Boschini, A.D., J. Pettersson, and J. Roine, Resource curse or not: A question of appropriability. The Scandinavian Journal of Economics, 2007. 109(3): p. 593-617.

15. Shleifer, A. and R.W. Vishny, Corruption. The quarterly journal of economics, 1993. 108(3): p. 599-617.

16. Bardhan, P., Corruption and development: a review of issues. Journal of economic literature, 1997. 35(3): p. $1320-1346$.

17. Berg, A., J.D. Ostry, and J. Zettelmeyer, What makes growth sustained? Journal of Development Economics, 2012. 98(2): p. 149-166.

18. Torvik, R., Natural resources, rent seeking and welfare. Journal of development economics, 2002. 67(2): p. 455-470.

19. Acemoglu, D. and J.A. Robinson, De facto political power and institutional persistence. The American economic review, 2006. 96(2): p. 325-330. 
20. Acemoglu, D., S. Johnson, and J.A. Robinson, Institutions as a fundamental cause of long-run growth. Handbook of economic growth, 2005. 1: p. 385-472.

21. Sala-i-Martin, X. and A. Subramanian, Addressing the natural resource curse: An illustration from Nigeria, in Economic policy options for a prosperous Nigeria. 2008, Springer. p. 61-92.

22. Adenikinju, A. and N. Falobi, Macroeconomic and distributional consequences of energy supply shocks in Nigeria. 2006.

23. Werlin, H.H., The consequences of corruption: The Ghanaian experience. Political Science Quarterly, 1973. 88(1): p. 71-85.

24. Mbaku, J.M., Bureaucratic Corruption in Africa: The Fultility of Cleanups. Cato J., 1996. 16: p. 99.

25. Mbaku, J.M., Bureaucratic corruption as rent-seeking behavior. Konjunkturpolitik, 1992. 38(4): p. 247-265.

26. Udah, E.B. and U.R. Ogbuagu, Constraints to Economic Development and Growth in Nigeria. 2011.

27. Iyoha, M.A. and D. Oriakhi, Explaining African economic growth performance: The case of Nigeria. Revised Interim Report on Nigerian Case Study, Prepared for the African Economic Research Consortium Research Project, Explaining African Economic Growth Performance, 2002.

28. Stevens, P., Resource Impact-Curse or Blessing? Investment Policy, 2003. 22: p. 5.6.

29. Sachs, J.D. and A.M. Warner, Natural resource abundance and economic growth, 1995, National Bureau of Economic Research.

30. Sachs, J.D. and A.M. Warner, The curse of natural resources. European economic review, 2001. 45(4): p. 827-838.

31. Manzano, O. and R. Rigobon, Resource curse or debt overhang?, 2001, National bureau of economic research.

32. Mehrara, M., Reconsidering the resource curse in oil-exporting countries. Energy Policy, 2009. 37(3): p. 1165-1169.

33. Pegg, S., Is there a Dutch disease in Botswana? Resources Policy, 2010. 35(1): p. 14-19.

34. Harberger, A.C., Observations on the Chilean economy, 1973-1983. Economic Development and Cultural Change, 1985. 33(3): p. 451-462.

35. Duruigbo, E., The World Bank, Multinational Oil Corporations, and the Resource Curse in Africa. U. Pa. J. Int'l Econ. L., 2005. 26: p. 1.

36. Ogunleye, E.K., Natural resource abundance in Nigeria: From dependence to development. Resources Policy, 2008. 33(3): p. 168-174.

37. Rabiner, L.R., A tutorial on hidden Markov models and selected applications in speech recognition. Proceedings of the IEEE, 1989. 77(2): p. 257-286.

38. Rabiner, L. and B. Juang, An introduction to hidden Markov models. ieee assp magazine, 1986. 3(1): p. 416.

39. Bunke, H. and T. Caelli, Hidden Markov models: applications in computer vision. Vol. 45. 2001: World Scientific. 
40. Hamilton, J.D., A new approach to the economic analysis of nonstationary time series and the business cycle. Econometrica: Journal of the Econometric Society, 1989: p. 357-384.

41. Engel, C. and J.D. Hamilton, Long swings in the dollar: Are they in the data and do markets know it? The American Economic Review, 1990: p. 689-713.

42. Krolzig, H.-M., Predicting Markov-switching vector autoregressive processes. 2000: Nuffield College.

43. Krolzig, H.-M., Business cycle measurement in the presence of structural change: international evidence. International Journal of Forecasting, 2001. 17(3): p. 349-368.

44. Easterly, W., et al., Good policy or good luck? Journal of Monetary Economics, 1993. 32(3): p. 459-483.

45. Acemoglu, D., S. Johnson, and J. Robinson, An African Success Story: Botswana” forthcoming. 2001.

46. Acemoglu, D. and S. Johnson, Unbundling institutions. Journal of political Economy, 2005. 113(5): p. 949995. 